\section{NOTES ON METEORITES.}

VI.

COMETS ARE METROR-SWARMS WHICH HAVE FNTEREI) THE SOLAK SYSTLM SUME TIME UR OTHER.

- IIESE swarms, then, are comets. The tinal demonstration, as we have seen, we owe to the labours of Newton, Arlams, and Schiaparelli chiefly. but long before their time the connection between shooting -stars (and even meteorites) and comets had been suspected on various grounds."

Many shooting stars pass through the air with a trail. Thi. alpearance is certainly suggestive of a very rapid comet. Hence, jerhaps, it was that such an appendage, often noticed in the case of briglit metcors, was sometimes in afcient records described a i a comet. It is known that Cardano described as a comet the great meteor from which fell 12 costones on the teritory of Crima om September $4,1511 .^{3}$

Cot only, as we have seen, Kepler $(1600)$ regarded shooting stars as ahin in nature to meteorites, but he held that both hici the same origin as comets:- "Falling stars are compo:ed of inflammatory viscous materials. Sieme of them disappear during their fall, while others indeed fall to the earth, drawn by their own weight. Nor, incled, is it improbable that they have been formed into globes from feculent materials mixed with the ethereal air itself, and throm $n$ from the ethereal region in a straight line through the air like very small comets, the cause of the motion of boih being hidien." 4

Halley (17co) though he thought that the phenomenon of shooting stars ${ }^{3}$ was produced by a material disseminated through celestial space falling upon the sun and metting the uarth in its jassage, did not associate it with cometary phenomera; but Maskelyne $\left(176_{5}\right)$ held that meteors were of celestial origin, and was inclined to assinilate them to comets. He wrote a follows in a letter to the Albbe ('esaris, the a-tronomer at Milan, about December 12, $178_{3}:-$ "Frevly accept, I pray you, thi map, which I have lately published in order to stir up learned men rather than the unlearned, to observe more keenly the phenomena called fire-balls. In all probability they will turn out to be comets. . . "

To Chladni belongs the credit of having broached the theory which morlern observations have established.

We have already seen that Chladni formulated the view, in 1794, that space is filled with matter. In 1819 he extended it by stating that both shooting-stars, meteotites, and comets were but different manifestations of it. ${ }^{7}$

Chladni made a step in this matter of which, as pointed out by Scbiaparelli, only to-day are we able to appreciate the importance. In suggestingr the cosmical hypothesis, he regarded two possible cases : either the meteors were formed of masses of independent materials which had never formed part of the larger celestial bodies, or they are the result of the destruction of a celestial body previously existing. Chladni held the second hypothesis as possible. but held to the first as more probable. He stated that we could not doubt the existence in the celestial space of small bodies endowed with mosement, which are now and then visible by passing before the sum.

He held, therefore, that the small masses which appear under the forms of bolides and falling stars do not differ essentially from comets. It is also probatile, he says, that comets consist of clouds composed in gicat part of masses of vapour and dust, which are kept together by mutual attraction. That this attraction is not enough 10 sensibly disturb the planetary movements is a proof of the exceeding tenuity and dispersion of the materia!s in such clouds, through which, however large, it is possible, to observe the fixed stars."

In 1839 the Abbe Raillard suggested a connection between luninous metcurs and comets and the aurora, ${ }^{y}$ and Dr. Forster

i Continued from vol. xxxviii. p. fos.

Fur many referemes in what folliows 1 am injebecd to the historical me tice in schiaparelli"s "siéle ciadente"

"Humbeld1," Cosmos," iv. p. $5^{37}$ (Utté). (Cardani, "Opera." J.ugdani,

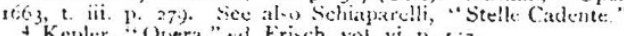

Kepler, "Opera," al triech, vol. vi. p' $\mathrm{t}_{i}$ ?

5 Coulver. (iratier et Sargey, “. Introd. Hi-toriqu.," p.

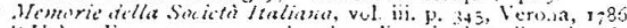
" Veber fenermeteure, und ueber die mic cienselben heralgefaltenen

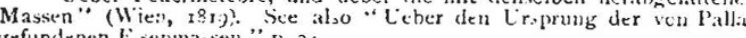
kefundenen E.senama. sen," p. 24.

8 "Feuerneteure," p. 395; sec Kaent/, "Meteorsl.gie," vol. ii. p. 316

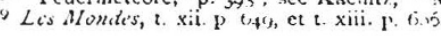

noted that the jears marked by the appearance of a large comet are remarkable also for the abundance of falling stars, especially of white ones.

Ferhaps the first to give a more solid support to the cometary theory of falling stars on geometric grounds was Roguslawski, who conccived the idea of representing by means of parabolas the apparent orbits observed in some of the August meteors of I8 $37 .^{2}$

For the next important advance in thought upon this subject we have to correc duwn to 1858 , in which year. Baron Reichenbach publishel a most important remoir ${ }^{3}$ atlacking the question from an entirely new point of view. leichenbach, accepting as proven by the then hrowlcdge the most intimate connection between meteorites and falling stars, reasoned in the following manner, that both were conrected with comets. He first recapitulated the facts then accepled with regard to coinets :-

(1) Coarcts, both taii and nucleus are transparent.

(2) Light is transmitted through comets with ut refraction; hence the conetary substance can be neither gascous nor liquid.

(3) The lights is polarized, and therefore borrowed from the sun.

(4) Comets have no phises like those of moon and planets.

(5) They exercise no perturbing influences.

(6) I) onati's comet (which was then visible) in its details and its contour is changing every day-according to l'iazzi, almost hourly.

(7) The density of a comet is extremely small.

(S) The absolute mass is sometumes small (von I,ittrow having calculated very s.nall comets, tail and all, as scarcely reaching $\$$ pounds).

From these data the following conclusions might be drawn :-

(1) That a comet's tail nuust consist of a swarm of extremely small but s.jicl particles, therefore granules.

(2) That cvery granule is far away from its neighbour--in fect, si) far that a ray of light may have an uninterrupted course through the swarm.

(3) 'That these granules, suspended in space, move freely and yicld to outer and inner agencies-agglomerate, condense, or expand ; that a comet's nucleus, where one is present, is nothing else than such an agglomeration of loose substances consisting of farticles.

Hence we must pictlire a cmet as a loose, transprarent, illamina:ed, free-moving swarm of small soid granules suspented in empty space.

The next step in Reichenbach's reasoning was to show that meteorites (of which he had a profound knowledge) were really composed of granules.

He pointed out that these granules (since called chondroi) formed really the characteri-tic structure both of irons and stunes, so that both orders were chiefly aggregates of chondroi-stony ones in iron metenrites, iron ones in stony meteorites.

In some irons, such as Zacatecas, they exist as big as walnuts, firmly adherent, but they can be separated ; inside these are balls of troilite, often firmly cmbedded, so that on breaking the meteorite they will divide, but in wher cases so loose that they fall out, and they are smooth enough to roll off a table.

Sometimes chondroi have smaller ones sprinkled in them, sometimes darli chondroi have white earthy kernels.

In some cases these chondrui aie so plentiful as to form nearly the whole mass of the meteorite. They are often perfectly round, but not always, and they are often so loose that they tumble out and leave an empty smooth spherical cavity.

The stones chicfly consist of such chondroi and their deteris.

IIe adds that each magnesic chondros " is an independent crystallized indiviclual-it is a stranger in the meteorite. Fvery chondros was once a complete, independent, though ninute meteorite. It is emberlicd like a shell in limestone. Millions of years may have passed between the formation of the spherule and its embeddal."

He then goes on to remark that the chondroi of metcorites indicate a conclensation of innumerable bodies such as we see must exist in the case of comets; further, that they have heen formed in a state of unrest and impact from all sides. Many meteorifes are true breccias; they have many time'; sufferec mechanical violence. He then shows that in comets we have precisely the conditions where such forces could operate, ant

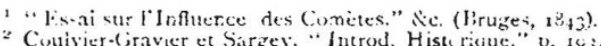

"Conivier-linaver et Sargey, "Introd. Hist
} 
hence arrives at the view that "comets and meteorites may be nothing else but one and the same phenomenon." 1

This was in $\mathbf{1} 858$, eight years before Schiaparelli's discovery.

Newton, as we have seen, referred the comet of 1862 to the largest meteorite in the August swarm.

We may assume from the work which has already been done that Reichenbach's view is more probably the true one, and that the head of a comet is merely the denser part of the swarm. Whether that denser part is at the end or at the beginning of the long line to which reference has been made, it does not very much matter, but where that is there we shall have the appearance of a comet presented to us in the heavens. That being so, we are able to apply everything that we have learned about comet; to the movements of meteorites in space; in the case of meteors and falling stars we were limited to what took place in our own air.

The Appeararce; presented by Comets away from the Sun.

When a comet first becomes visible, it appears in the telescope as a round misty body, and moves very slowly in consequence of its still great distance from the sun. At this time, too, its light is very feeble. Its appearance under these con-

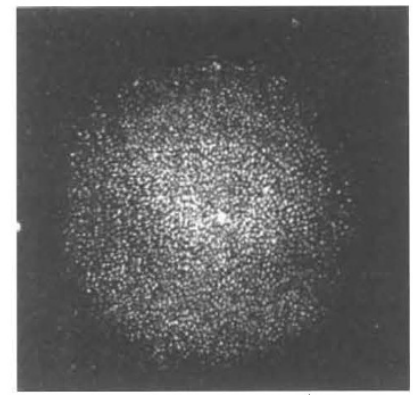

FIG. 12. - A comet near aphelion.

ditions strikingly resembles that of a nebula, and in fact comets have often this been mistaken for nebulæ.

Occasionally the appearance put on is that of a planetary nebula in small telescopes and a globular one in larger ones.

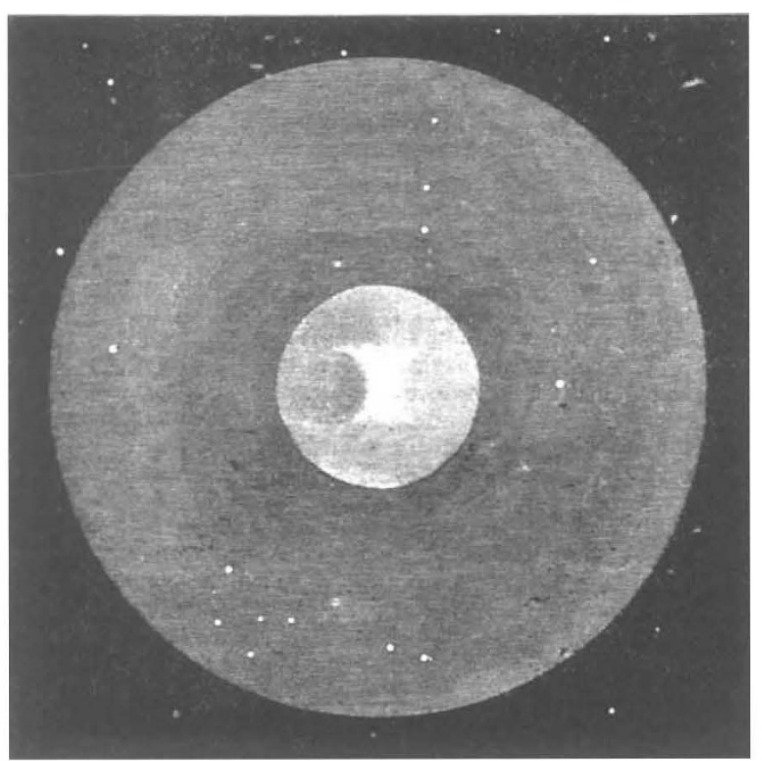

FIG. 13.-The Pons-Brooks conet, January 13, $183_{4}$ (Thollon).

The globular form, after a time, gives way, and the concentration of light is now a star-like concentration at one end of an elliptic patch.

${ }^{x}$ For this analysis of a part of Reichenbach's memoir, I am indebted to my friend Mr. L. Fletcher, of the British Museum.
In the next phase, both the star-like object and the elliptic patch lengthen, and the appearance becomes more like what is ordinarily recognized as a comet.

As the comet approaches nearer the earth, so that observations of its several portions may be seen, we get a still greater differentiation of the phenomena.

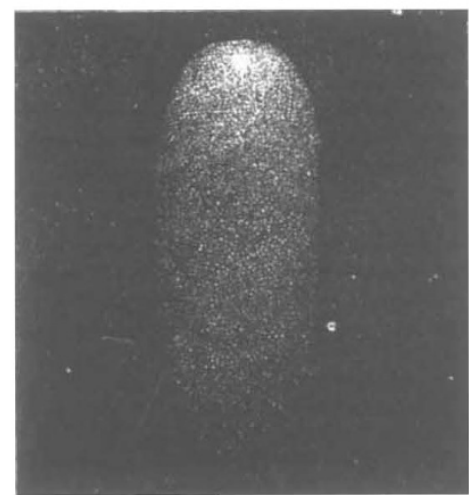

F1G. 14.-The first te ginnings of a tail.

Fig. 16, which is a representation of Donati's comet as it appeared in 1858 , will serve to illustrate the main characteristics of comets. The brighter part is called the head or coma, and sometimes there is within this a still brighter and smaller portion called the nucleus, The tail is the dimmer part radiating from the head,
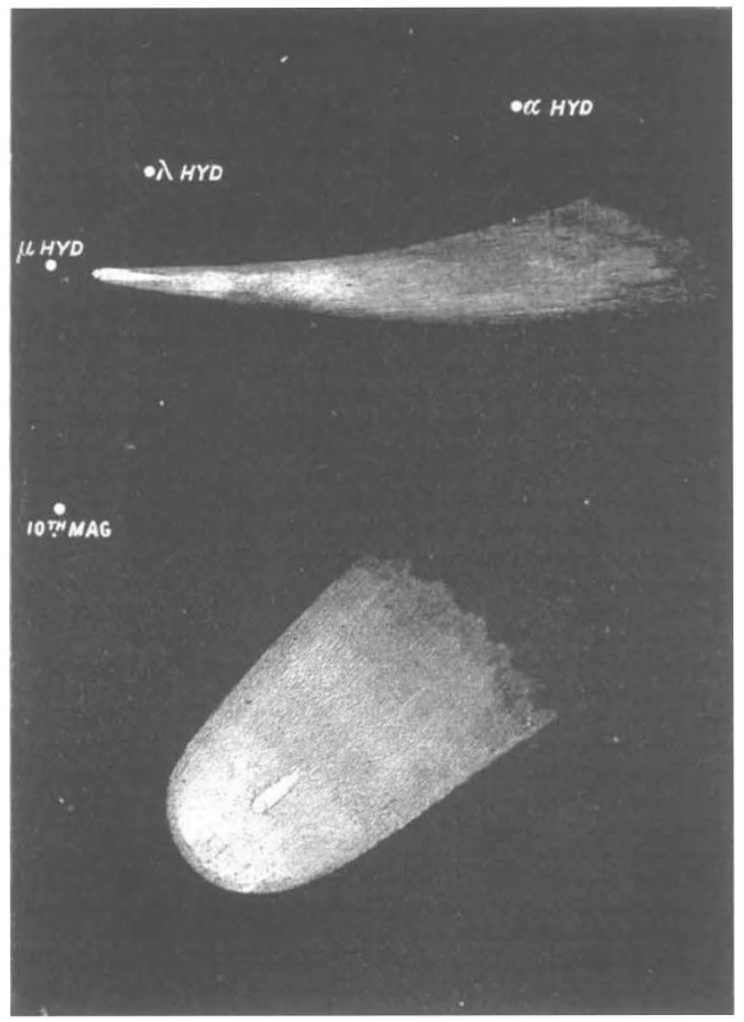

E1G I5-The lower portion represents the elongation of the star-like luminosity; the upper one. the con; $\mathrm{cm}$ tant extens.on of the whole comet (Comet I882 October 25, Seabroke).

and this varies greatly in different comets ; it may be long or short, straight or curved, s ngle, doulle, or multiple. The comet of 1744 had six tails, that of 1823 two. In others the tail is entirely absent. The tail of the comet of $186 \mathrm{r}$ was $20,000,000$ miles in length, and that of the comet of 1843 was $112,000,000$ miles long. 
Boih head and tail are so tran-parent that all but the faintest stars are casily seen throngh them. The star Arcurus was seen th:ough the tail of bonati's comet in 1859 at a place where it wis 90,000 miles in diancerer.

As a comet approaches the sun its velucity, like that of the planets, increases, and it gradualby gets hotter ard sives out more light.

When the comet gets sufficiently hot, aisrettes or jits make their appearace; these ste socallid hecme the; secm to shoot

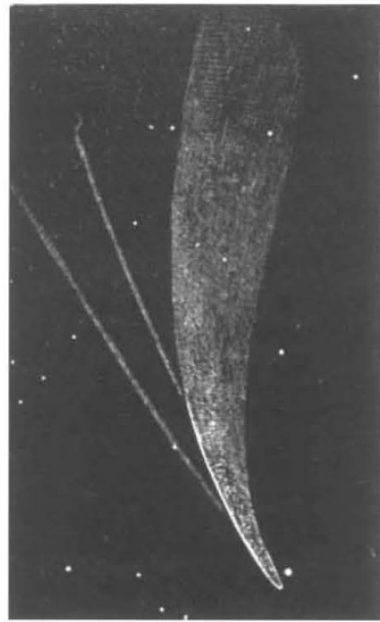

J Ic. 16.-Lunati's com: ('‘eneral iew!

out from the nucleus like sparks shoo: out from a squib. The jets rapidly change their positions and cirection", and the tail is formed, apparently at the expense of the matler of which the head was in the first instance built up. The tail is always turned from the sun, whether the comet be approaching or receding.

I)rawings of a comet, as seen at difiesent times, show how th: jets vary in appearance and direction. Instead of jets, some comets present phenomena of a very difierent character, called envelopes, which are thruwn off c-nceritrically from the nucleus.

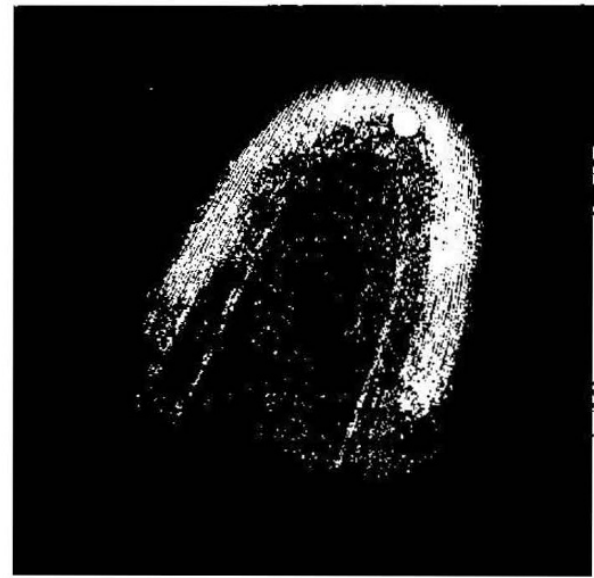

Fic. 17.-Conct with singie nucieus (Crui's come', 1882 , Riccis),

These are among the chief physical peculiarities about the heads of comets; and we see at once that we have something perfectly distinct from the planets, and that some comets are at first sight different from others. The envelopes have been observed to rise from the nucleus with perfect and exquisite regularity in exactly the same way that the jets swing backwards and forwards.

The enormous effect produced by a near approach to the sun may be gathered from the fact that the comct of 1680 , at its perihelion passace, while travelling at the rate of $\mathrm{I}, 2 \mathrm{CO}, \mathrm{CcO}$ mile an hour, in two days shot wut a tail 60,cco, oco miles in length.

We must now enter somewhat more into details with regard to some of these cometary characteristics.

First of all, it must be pointed out that the neteoritic swatms

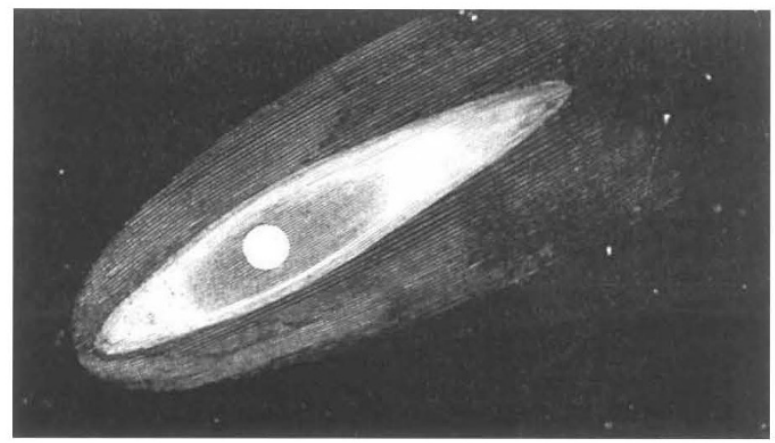

F:cj. x3,-Nuclet:s surrounde 1 by ellipoidal head (Comet $\mathrm{ISS}_{2}$ (Octolser 25, in Wasliungton refractor).

are not always single, for in some comets the nuclei are double or triple.

In the case of single nuclei the nucleus may be the origin, and lie in the brighter region the extension of which forms the

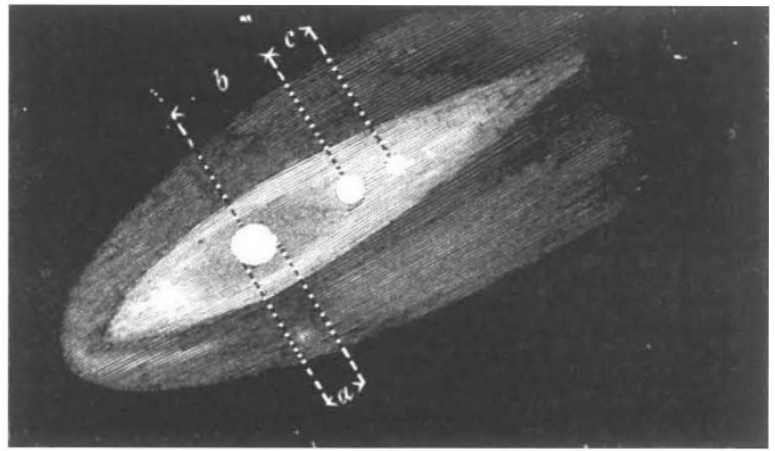

Fic; r. -Compound nucleus (same comet November 5 ).

tail. But this is not invariable: the nucleus may be caught forming part of an elliptic head (Fig. 18) before any very great extension of the tail begins to take place, owing to reasons which will be stated further on.

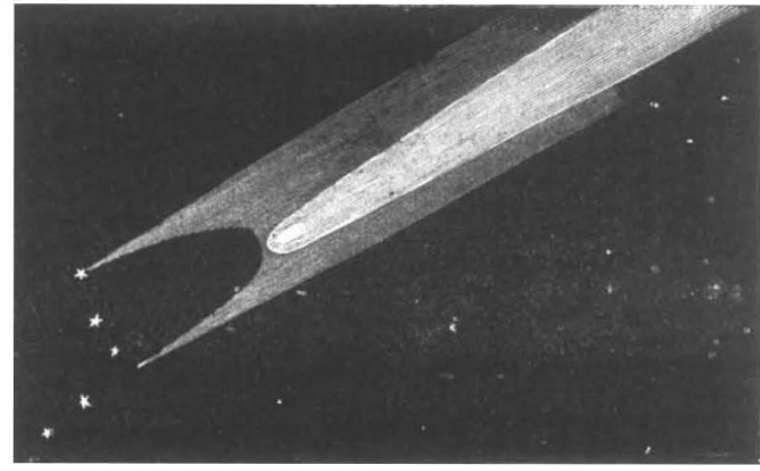

Fi:; 20.-Conmander Sampson's sketch of the great comet, 1832, ()ctober ro.

In the case of double or multiple ruciei we have a clear indication of the existence of more than one chief meteritic swarm, whether they be enveloped in the same atmosphere or give rise t) the same tail (Fig. 19). But it would seem that, in 
some cases, difierent nuclei may give rise in separate tails such 'xould seem a posible cxplanation of Commander Sampson's olservation of the comet of $I 892$ (Fir. 20 ).

I. NuRMAN I,ICKYER.

(Tilic continuil.)

\section{THE AVVIVERSARY WEETIN OF THE KOYAL SOCIETY.}

THE anniversary mesting of the Royal Society was held on Friday last, st. Andrew's Lav. The President read the anniversary address-a copy of which has not yet reached us -and presenteri the medals. F' $r$ if. Huvley receiverl the Copley Medal, and Mr. Crookes the Davy .II edal in person. Prof. Osborne Reynolds was a'so present in reccive one of the Royal Medals. The other Royal Medal was received on behalf of Baron von Mueller by Sir (irahan licrry, Agent. (ieneral for Victoria, and the Kuniford Medal, which liad been awarded io Prof. Tacchini, was received on his behalf by the Chevalier Catalani, the Charre d"Afjairis at the Italian Fmbzsis. The Society next proceeded to elect the officers and Conncil fis: the cnsuing year. The selected names we have alrearly pablished.

In the evening about 175 Fellows and guests dincd wrether at 11 illic's Roonli. Among the guests were eminent represcutative; of the English fioverninent, of foreign nations, ant of art and

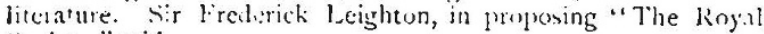
Society," said :-

"A great honour is do te to me in in:rustins to my hands the toast which I have risen to projpoie, for it is the tonat round which the chice sympathies of those who sit at this ta'sle are centred, be they hoits or be they gues's-namelv, prosperity to that ancient and honoured body, the Royal Society. It is, indeed, a toast favoured in this-that no inadequacy of present. ment could rob it of your warm reception, but it is onc, also, which, in one senae, the indivitual now before you is s) little fitter to propose that $l$ conld almo $t$ suspect you, Sir, of a little prompting of hum $2 u r$ in your selection. I do not mean becailsc the bodies with which you and I have respectively the honour to be connected arc now, in Piccadtlly, as they were in furmer day's in Somerset linuse, next-dioor neighbours, and because it is not habitually to one's next.door neigbbour that one looks in life for a kind words but on this other and more cogent ground - hat the subject on which yoil bill m: spea's is one in regaril :o which I an entirely ig iorant, and that my attitule is therefore not fice from ludicrous aspect in the face of a b xly to which grasp and accuracy of knowledge is the ore thin a nee Iful, and precision of sta:ement the first duty of ma:1; and thi- Sir, certainly no: least in the day of your healihip. Ant ye: on closer viese, it is not knowledye, perhapt, that you require of the proplser of this toat sn much a: revpesiful iympathy; and that you fin t in me to the full. No, gentlemen, yould not demand in me knowledise treyond that of the average irnoramus who wathe you in wo whe as you so:Ind with divining eres the realms of the heavens above and of the ear'h beneath and of the water under the earth, an:l lay bare before us the very leat of the life-pulec of Nature. Yo: demant in m: I say, rather, sone symputhetic sense of your magnificent misimas, srme adhe ion th the faith that you pro fess, and forthese you d s not look to me in vain. It happens to me, Mr. I're-itent, fron time to time to have: to acknowledire words of recosnition of the survices of the great institution to which I am beind in a like capncity with your own; and, knowing how earnestly that bojy is hent on the worthy discharge of an arduous task, such word, are decily yrateful to in:, but in evcry such case I see in my inner mind, behind and above the institution which I scrve, the sweet and sercne countenance of our divine mistress-of Art herself; and so, also, in offering this tonst to the acela mation of your guests an t to the acceptance of your flock, I am thinking less of the noble services of your renowned soriery. less of the many names which are it: high ad remment at this time and our country's pride, than of you mistress beneficent and supreme, the seatterer of darknessscience. All of us walk in the daylight of her illumination, the hunblest layman can beat witness :o ber, aist the must iwnorant concerning the pathe she treats may yet not unbecominals de clare his gratitude to her ministers, an lexpess, as I now copress, the hope that they and their saccesors may in the liond of this constituted brotherhoud lon: continue to tend the flume and feed the increasing splendiur of her sacred in weinguwhable l.ımı."."
The President of the Royal Society responded in a short speech, in which he compared the koyal Siscicty to a wave of light moving onward through space, conveying intellirence from one portio:l of the universe to another far-distant portion. The molecules which it set in motion had but a brief existence, but the walve moved ever unwari.

\section{SCIENTIFIC SERIALS}

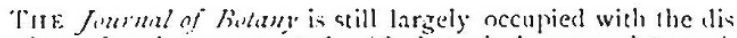
cussiun of points connected with botanical nomenclature, in which linglish, American, and Genevan botaniststate part. The Octolier number contains also a description of a new genus of Sierberidace iv by the Japanese botanist Tokutaro Ito.- In t'se November number are papers on the genus (iar'x, by . Mr. I., II liniley ; 0 . Ferns from IVest Borneo, hy Mr. I. (;. liatier; on somth llerlyshice plants, by Rev. W. R. Linton : and on the Dusmicli of Maine, by Mr. W. West. Mr. W. H. Beelyy records the interesting fact that of the two very nearly allic I secies of valerian, lizieriana . Mikanii and samluacifolia, one is very attractive to cats, while to the other they are quite indifferent.

Ix the Binnial Gazitle for Septemler, Mr. C. Ro'verison completes his csiay on zygomorphy and its causes, summing up the results of his observations. The remainder of the number is lar.ely nocupied by abstracts of botanical paperivent at the (C)eland mecting of the American Association for the . Hrancement of stience. - In the October number are two important anatomical preers, by Miss Finily L. Gregory on the develop. ment of cork-wings on certain trees, and an illustrated one by Mr. II. II. Evans on the stem of Epheitra, Mr. (i. Varey contribute; an interesting article on the charactcristic vesetation of the Nurth American desert.

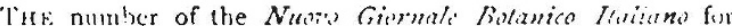
Octoler iSSS is entirely occupied hy reports of the papers reat before the annual meeting of the Botanical Sincicty of Italy held at florence in September, many of which are of consilerable intere t. - Sig. (. Massol.ongo descrites the germination of the

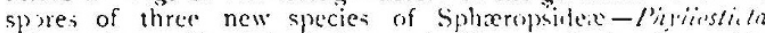

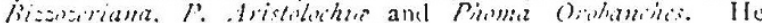
maintain-that the only difference between pyenidia and spermogrnia is that the sporules (stylospores) contained in the former are camable of germinating direcily, while those formed in the Intter spermatia! have no stch power.--Sig. . 1. . Berlese

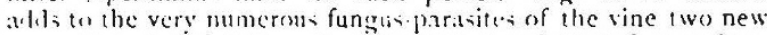

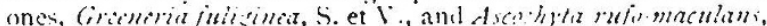
Bert.-Sin. 1i. Gasperini has investigated the nature of the organism: which bring about the fermentation of the palus wine known to the Arabs under the name of "leriliz." Jle finds it

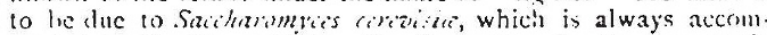
panicel by fiacillus subtilis. On the surface is also commonnly

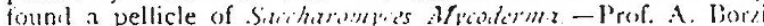
decrithes a new epecies and genus of $A$ scomycetes- Finm. firium Combalingia, found on half ripe capsules of limaria (ymblaria. - The littleknawn germination of the seeds of the warer-lily, Eurvale foro.; is described by Sig. (i. Arcingeli, the chief peculiarity bein: the almost entire stappres-ion of the c) ongation of the ratlicle.- Prof. I. Macchiati claims to have discriered an entirely new substance, which he calls $x$ tamtht. pitrilitrin, as a constituent of the green colouring matter of plant: It is erystallizable, and allogether distinct from $\left.x 3^{\prime}\right)$ thophyll ant from the pigment of yellow petals, - Prof. $A$. Porzi cleserites the mole in which xirotroplim displays itself in some ferni-

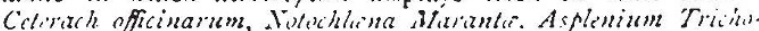
mants, and several species of Cheilunthes : understanding hy this term the mechanical contrivances by which an organ protec:s itielf arainst excessive desiccation.

\section{SOCIETIES AND ACADEMIES. Lonnon.}

Royal Society, November 22. "The Waw' on a rotaling Liquicl Spheroit of finite Follipticity." By (i. H. Bryan, 13.A. Communicated hy l'rof. C. It. Darwia.

The hytrodymamical problem of tialing the waves or oxilla tions on a gravitating mass of liquid which when undis'urbed is rotating as if rigid with finite angular velucity in the form of an ellipiond or spheroit, was first stecessfully attacked by .II. Puincare in 1585 